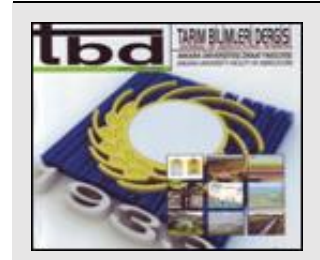

Tarım Bilimleri Dergisi

Journal of Agricultural Sciences

Tar. Bil. Der.

Dergi web sayfası:

www.agri.ankara.edu.tr/dergi

Journal homepage:

www.agri.ankara.edu.tr/journal

\title{
Effects of Different Germinated seeds Flour on Mineral, Phytic Acid and Total Phenolic Content of Cookies
}

\author{
Hatice TOK ${ }^{\mathrm{a}}$, Nilgün ERTAŞ ${ }^{\mathrm{a}}$ \\ ${ }^{a}$ Department of Food Engineering, Engineering and Architecture Faculty, Necmettin Erbakan University, Koyceğiz Campus, Konya, 42050, TURKEY
}

\author{
ARTICLE INFO \\ Research Article \\ Corresponding Author: Nilgün ERTAŞ, E-mail: dr.nilgunertas@gmail.com, Tel: +90 (332) 2808046 \\ Received: 04 March 2019, Received in Revised Form: 21 June 2019, Accepted: 06 August 2019
}

AUTHORS ORCID ID:

(Hatice TOK: 0000-0002-8982-6428), (Nilgün ERTAŞ: 0000-0002-0671-2485)

\begin{abstract}
The effects of germination at different germination period $(1,3$ and 5 days) on physical, chemical and nutritional properties of three different seeds (wheat, rye and lentil) were investigated. Germination caused significant increase in ash, protein, total phenolic content, minerals $(\mathrm{Ca}, \mathrm{Mg}, \mathrm{Fe}, \mathrm{Zn}, \mathrm{K}, \mathrm{P})$ and phytic acid loss. As the germination period increased, $\mathrm{L}^{*}$ values decreased, $\mathrm{a}^{*}$, $b^{*}$ and SI values increased. Germinated seed flours (GSF) were
\end{abstract}

substituted for wheat flour at different ratios $(0,5,10$ and $15 \%)$ in cookie formulation to improve nutritional properties. The addition of GSF in cookie formulation gave lower phytic acid content than the control cookie sample. The highest calcium and magnesium content of the cookies were determined with germinated rye flour (GRF); the highest iron, potassium and zinc value were obtained with germinated green lentil flour (GGLF). The use of $5 \%$ level had caused similar taste values to the control cookie samples.

Keywords: Germinating; Mineral; Phytic acid; Total phenolic content

(c) Ankara Üniversitesi Ziraat Fakültesi

\section{Introduction}

Cereals that are used in products such as bread, pasta and cookies and had a very important place in human nutrition due to the energy are the edible constituent of the grain. Legumes can be used effectively to meet the protein deficiency required for healthy and balanced nutrition in the world and in our country they are our important plant sources. Various processes (fermentation, germination, autoclaving, milling, heat application) are applied in order to ensure more efficient use of this important plant sources thus nutritional content is enriched and antimicrobial factors are reduced. Nowadays, the production and consumption of the germinated products in the world are increasing in both variety and quantity, as a result of the tendencies towards functional foods. One of the main reasons for this is that the germination process is not expensive and does not require complicated equipment (Lorenz 1980). In literature, some of the nutritionally important components such as vitamins, minerals, dietary fiber, flavonoids, phenolic acids and many antioxidant components, omega 3 type of fatty acids of plant seeds and cereals sprouts increases during germination, and also increase the functional properties of the products are stated (Siro et al 2008; Öztürk 2008). Wheat sprouts compared to wheat; in addition to higher vitamin content, it is stated that it has higher phenolic substance, higher quality protein, more aromatic amino acids and more polyunsaturated fatty acids (Öztürk 2008; Yang 2000). The phytase activity increases (Reddy et al 1982) and the phytic acid content decreases and the digestibility of the fibers and proteins changes during germination. Furthermore, the increase in amino acids and ascorbic acid contributes to the bioavailability of trace minerals (Lintschinger et al 1997). During germination, beta carotene, vitamin C and E content is increasing (Yang 2000). 
In studies, rye (Katina et al 2007), lentils (Urbano et al 1995), beans, peas (López-Amorós \& Estrella 2006), cowpea, chickpeas and mung beans (Ghavidel \& Prakash 2007), oats (Wilhelmson et al 2001), paddy (Kim et al 2012), lupine (Cunha-Queda \& Beirao da Costa 1994), barley (Sung et al 2005), brown rice (Moongngarm \& Saetung 2010) germinated.

Nutritional properties increased with germination process and germinated seeds are stated to be valuable resources of natural bioactive compounds and antioxidants. The amount of anti-nutrients decreased during the germination and after the germination, compounds with beneficial and phytochemical properties were formed. These substances are particularly important in many diseases prevention such as cancer. Thus, functional foods that protection of health and positively affected on human health can be developed by germination.

In this study, cereals and legumes (wheat, rye and green lentils) were germinated at different germination period (1, 3 and 5 days), dried and milled. Flours of cereal and legumes seeds were replaced by wheat flour at different ratios $(0$, 5,10 and $15 \%$ ) and cookie production was carried out to improve nutritional and functional properties.

\section{Material and Methods}

\subsection{Material}

To germinate the seeds; wheat, rye and green lentil were purchased from local market in Konya, Turkey. Wheat flour, shortening, powdered sugar, salt vanilla and sodium bicarbonate were purchased from local markets in Konya for cookie production.

\subsection{Germination of seeds}

Wheat, rye and lentil seeds were cleaned from all foreign material, broken and diseased grains. Seeds were germinated according to the jar method. Briefly, $100 \mathrm{~g}$ of cleaned seeds were placed in $500 \mathrm{~mL}$ of $0.07 \%$ sodium hypochlorite $(\mathrm{NaClO})$ for $30 \mathrm{~min}$ to sanitize and then washed ten times in tap water to neutralize $\mathrm{pH}$ and filtered with excess water. Then, the seeds were soaked in $1000 \mathrm{~mL}$ distilled water for 5 hours and shaken for 30 min so as to draw water. The jars were covered with a thin cheese cloth so that the seeds were contacted with air. Then water (kernels: water ratio of 1:2) was added. After rinsing several times, the water was removed from the jar. The seeds were sprouted in the dark at room temperature with watering every $12 \mathrm{~h}$ for $1,3,5$ days. At the end of 1, 3, 5 days germinated seeds were dried in 50 ${ }^{\circ} \mathrm{C}$ (Nüve FN-400) and grounded in a hammer mill. Ungerminated seeds were used as a control ( 0 day). The germinated seed flours (GSF) and wheat flour were placed in a large polyethylene bag and mixed thoroughly by hand.

\subsection{Production of cookies}

To prepare cookie samples; AACCI (Approved Method No: 10-54.01) method were used with some modifications. The dough was prepared in a laboratory mixer following a standard formulation by addition level of $0,5,10$, and $15 \%$ GSF ( 5 day germinated wheat, rye and green lentil flour). As a result of the preliminary experiments, it was decided that the 5-day germination period was the most suitable GSF for the use of cookie production. $100 \mathrm{~g}$ wheat flour (according to $14 \%$ moisture content), $40 \mathrm{~g}$ shortening, $40 \mathrm{~g}$ powdered sugar, $2 \mathrm{~g}$ sodium metabisulphite, $1.25 \mathrm{~g}$ salt, $1 \mathrm{~g}$ milk powder $0.5 \mathrm{~g}$ vanillin and variable water were mixed for $10 \mathrm{~min}$ at $125 \mathrm{rpm}$. Cookie dough were sheeted to $5 \mathrm{~mm}$ thickness with a rolling pin and shaped with a dough cutter $(50-\mathrm{mm}$ diameter) and baked on aluminum trays in an oven (Profilo, HG1503T) at $150{ }^{\circ} \mathrm{C}$ for $16 \mathrm{~min}$. The cookies were cooled for $30 \mathrm{~min}$ at room temperature and immediately used for further analyses.

Cookies were evaluated for physical characteristics, including diameter ( $\mathrm{mm}$ ) and thickness (mm) measured with a digital micrometer $(0.001 \mathrm{~mm}$, Mitutoyo, Minoto-Ku, Tokyo, Japan). Spread ratio was calculated as diameter divided by thickness of the cookies.

The cookie hardness and fracturability were investigated using the standard method AACC 74-09.01 by texture analyzer (TA-XT plus, Stable Microsystems, England). Hardness (as fracture force) of cookies with 3-point bending test using 3-point bending rig, trigger force of $50 \mathrm{~g}$, and load cell of $5 \mathrm{~kg}$. (Pretest speed: $1.0 \mathrm{~mm} \mathrm{~s} \mathrm{~s}^{-1}$, test speed: $3.0 \mathrm{~mm}$ $\mathrm{s}^{-1}$, posttest speed: $10.0 \mathrm{~mm} \mathrm{~s}^{-1}$, distance: $5 \mathrm{~mm}$ ). 


\subsection{Color measurements}

Konica Minolta Chroma Meter (Model CR-400, Konica Minolta Sensing, Inc., Osaka, Japan) was used for color measurement of cookies. The surface color of cookie was determined as average L* (lightness), a* (redness), b* (yellowness) values. $\mathrm{a}^{*}$ and $\mathrm{b}^{*}$ values were used to calculate the saturation index (SI) $\left(\mathrm{SI}=\sqrt{a *^{2}+b *^{2}}\right)$ and hue angle $\left(\mathrm{H}=\tan ^{-1}(\mathrm{~b} * / \mathrm{a} *)\right)$ values.

\subsection{Proximal composition}

Chemical composition of ungerminated seeds, GSF and cookie samples were determined following AACCI method (AACC 2000), for moisture (44-12), ash (08-01.01) and protein (46-12.01).

\subsection{Nutritional analysis}

Mineral content (potassium, magnesium, calcium, phosphorus, iron, and zinc) was determined in cookies using a wet

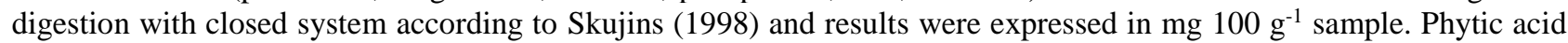
content of cookie samples was analyzed according to Haugh \& Lantzsch (1983) using colorimetric method. Total phenolic content of the cookies were determined based on Folin-Ciocalteu colorimetric method as described by Gao et al (2002) and Beta et al (2005).

\subsection{Sensorial evaluation}

Cookies were submitted to sensory analysis by twenty (20) semi-trained panelists (50\% male, 50\% female) that familiar with the quality aspects of baked products. Panelists evaluated typical attributes for cookie such as color, appearance, friability, taste, odor and general appreciation using a 5-point hedonic scale.

\subsection{Statistical analysis}

The significance of the variations observed among cookie samples was tested according to three way analysis and one way analysis of variance (ANOVA) using software program (JUMP, version 5.0).

\section{Results and Discussion}

The characteristics of GSF at 3 different germination periods were shown in Table 1 . A significant $(\mathrm{P}<0.01)$ difference in $\mathrm{L}^{*}, \mathrm{a}^{*}, \mathrm{~b}^{*}$ and SI values were obtained according to germinated seeds and germination period as a variance factors. Lightness values ranged from 79.31 for GRF to 82.73 for germinated wheat flour (GWF). According to germinated seeds variance, while GWF showed the highest lightness value, germinated rye flour (GRF) and germinated green lentil flour (GGLF) had the highest redness and yellowness, respectively. GGLF also showed the highest saturation index and hue angle vales among the GSF. After 5 day germination period, lightness values decreased, while the redness, yellowness and saturation index values increased. As expected, decrease in lightness, probably due to the Maillard reaction (between free amino acids and sugar content) during drying. The increase of the saturation index value could be due to the increase of reducing sugar during germination. Similarly Öztürk (2008) reported a decrease in L* values and increase in $a^{*}$ and $b^{*}$ values after germination. Likewise, Ertaş (2015) and Shin et al (2013) observed similar color changes for lupine and soy bean, respectively.

According to ANOVA results, germinated seeds and germination period factors affected the ash, protein, phytic acid and total phenolic content of GSF $(\mathrm{P}<0.01)$ significantly. Ash content of GSF varied between 1.26 and 2.80\%. GGLF possessed higher $(2.80 \%)$ ash content than the other GSF while the lowest ash values determined with GWF. Increasing germination period increased the ash content of GSF and the biggest change in ash content was observed after 5 day of germination. GGLF showed the highest protein content among the samples. This is due to its high protein content of green lentil compared to the other grains. During germination, increasing in protein content was observed. This result is in accordance with the study of Rosa-Millán et al (2019) who reported the significant increase in protein content of germinated bean compared to ungerminated bean. Total phenolic contents of GSF changed between $2056.38 \mathrm{mg}$ GAE $\mathrm{kg}^{-1}$ (for GWF) and $3377.00 \mathrm{mg} \mathrm{GAE} \mathrm{kg}{ }^{-1}$ (for GGLF). 
After 5 day germination period significantly higher total phenolic content of GSF (57.17\%) was observed in comparison to ungerminated seed. Tarzi et al (2012) described that the phenolic compounds of acetone, hexane and methanolic extracts of germinated chickpeas were increased as 53.7, 60.1 and 92.8\% during the germination, respectively. During germination marginal increase (104.95\%) was observed with GGLF (data not shown). In a study of Zilic et al (2014) total phenolic content of 5 day germinated wheat sample was increased from $1431 \mathrm{mg} \mathrm{GAE} \mathrm{kg}^{-1}$ to $1627 \mathrm{mg} \mathrm{GAE} \mathrm{kg}^{-1}$. Also an increase in total phenolic content in germinated rye sample compared to raw rye sample reported before by Katina et al (2007). Yeo \& Shadidi (2017) found that the total phenolic content of lentil seed as 6.75 GAE $\mathrm{mg} \mathrm{g}^{-1}$.

Table 1-Effects of germinated seeds and germination period on the color and nutritional properties of germinated seeds ${ }^{1}$

\begin{tabular}{|c|c|c|c|c|c|c|c|}
\hline \multirow{2}{*}{ Properties } & \multicolumn{3}{|c|}{ Germinated seeds flour } & \multirow{2}{*}{$\begin{array}{l}\text { Ungerminated } \\
\text { seed (mean) }\end{array}$} & \multicolumn{3}{|c|}{ Germination period (day) } \\
\hline & $G W F^{2}$ & $G R F$ & $G G L F$ & & 1 & 3 & 5 \\
\hline $\mathrm{L}^{*}$ & $82.73^{a}$ & $79.31^{b}$ & $79.50^{b}$ & $83.40^{\mathrm{a}}$ & $83.12^{\mathrm{a}}$ & $80.61^{b}$ & $74.92^{\mathrm{c}}$ \\
\hline$a^{*}$ & $1.33^{\mathrm{b}}$ & $2.11^{\mathrm{a}}$ & $-0.75^{c}$ & $0.14^{\mathrm{d}}$ & $0.85^{\mathrm{b}}$ & $0.56^{\mathrm{c}}$ & $1.78^{\mathrm{a}}$ \\
\hline$b^{*}$ & $12.33^{c}$ & $13.65^{\mathrm{b}}$ & $21.39^{\mathrm{a}}$ & $14.60^{c}$ & $15.61^{b}$ & $15.66^{\mathrm{b}}$ & $17.29^{\mathrm{a}}$ \\
\hline $\mathrm{SI}^{3}$ & $12.41^{\mathrm{c}}$ & $13.81^{\mathrm{b}}$ & $21.43^{\mathrm{a}}$ & $14.66^{\mathrm{c}}$ & $15.73^{b}$ & $15.75^{\mathrm{b}}$ & $17.41^{\mathrm{a}}$ \\
\hline Hue angle & $83.68^{b}$ & $81.09^{c}$ & $92.05^{\mathrm{a}}$ & $85.99^{\mathrm{ab}}$ & $85.78^{b}$ & $86.85^{\mathrm{a}}$ & $85.83^{\mathrm{a}}$ \\
\hline Ash $(\%)$ & $1.26^{\mathrm{c}}$ & $1.83^{\mathrm{b}}$ & $2.80^{\mathrm{a}}$ & $1.75^{\mathrm{c}}$ & $1.99^{\mathrm{b}}$ & $2.05^{\mathrm{b}}$ & $2.07^{\mathrm{a}}$ \\
\hline $\operatorname{Protein}^{4}(\%)$ & $13.46^{\mathrm{b}}$ & $13.00^{\mathrm{c}}$ & $22.67^{\mathrm{a}}$ & $15.31^{\mathrm{c}}$ & $17.16^{\mathrm{a}}$ & $15.98^{\mathrm{b}}$ & $17.05^{\mathrm{a}}$ \\
\hline TPC5 (mg GAE kg-1) & $2056.4^{c}$ & $2665.0^{\mathrm{b}}$ & $3377.0^{\mathrm{a}}$ & $2185.2^{\mathrm{d}}$ & $2347.2^{\mathrm{c}}$ & $2817.8^{\mathrm{b}}$ & $3434.3^{\mathrm{a}}$ \\
\hline Phytic acid (mg $\left.100 \mathrm{~g}^{-1}\right)$ & $865.8^{b}$ & $654.2^{c}$ & $963.2^{\mathrm{a}}$ & $1250.9^{\mathrm{a}}$ & $1136.1^{b}$ & $593.4^{\mathrm{c}}$ & $330.5^{\mathrm{d}}$ \\
\hline $\mathrm{Ca}\left(\mathrm{mg} 100 \mathrm{~g}^{-1}\right)$ & $71.92^{\mathrm{c}}$ & $84.89^{b}$ & $93.65^{\mathrm{a}}$ & $74.39^{\mathrm{d}}$ & $81.62^{c}$ & $84.24^{\mathrm{b}}$ & $93.68^{a}$ \\
\hline $\operatorname{Mg}\left(\mathrm{mg} 100 \mathrm{~g}^{-1}\right)$ & $132.57^{\mathrm{c}}$ & $160.39^{\mathrm{a}}$ & $145.07^{\mathrm{b}}$ & $110.23^{\mathrm{d}}$ & $151.06^{\mathrm{c}}$ & $156.79^{\mathrm{b}}$ & $165.95^{\mathrm{a}}$ \\
\hline $\mathrm{K}\left(\mathrm{mg} 100 \mathrm{~g}^{-1}\right)$ & $319.49^{c}$ & $521.17^{\mathrm{b}}$ & $1016.26^{\mathrm{a}}$ & $562.98^{d}$ & $611.97^{\mathrm{c}}$ & $656.09^{a}$ & $644.85^{b}$ \\
\hline $\mathrm{P}\left(\mathrm{mg} 100 \mathrm{~g}^{-1}\right)$ & $264.53^{c}$ & $358.01^{b}$ & $432.38^{\mathrm{a}}$ & $316.62^{d}$ & $350.58^{c}$ & $373.24^{\mathrm{a}}$ & $366.13^{b}$ \\
\hline $\mathrm{Zn}\left(\mathrm{mg} 100 \mathrm{~g}^{-1}\right)$ & $1.92^{\mathrm{c}}$ & $3.05^{\mathrm{b}}$ & $3.38^{\mathrm{a}}$ & $2.17^{\mathrm{d}}$ & $3.05^{\mathrm{b}}$ & $3.20^{\mathrm{a}}$ & $2.72^{\mathrm{c}}$ \\
\hline $\mathrm{Fe}\left(\mathrm{mg} 100 \mathrm{~g}^{-1}\right)$ & $2.23^{\mathrm{c}}$ & $3.17^{\mathrm{b}}$ & $6.58^{\mathrm{a}}$ & $3.54^{\mathrm{d}}$ & $3.94^{\mathrm{c}}$ & $4.20^{\mathrm{b}}$ & $4.30^{\mathrm{a}}$ \\
\hline
\end{tabular}

1, Means with same letter within row sharing a common letter are not significantly different $(\mathrm{P}<0.05)$. GWF, Germinated Wheat Flour; GRF, Germinated Rye Flour; GGLF, Germinated Green Lentil Flour; $\mathrm{SI}^{3}$, Saturation index $4 \mathrm{~N} \times 5.70$ for cereal flours; N $\times 6.25$ for non-cereal flours; TPC ${ }^{5}$, Total Phenolic content.

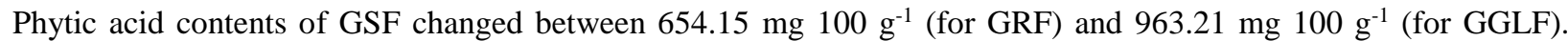
During germination phytic acid decreased and the lowest phytic acid value was observed after 5 day germination period. This is due to the increasing activity of phytase enzyme during germination. At the end of the germination period of approximately 7-8 days, the complete phytate content disintegration is reported (Ashton \& Williams 1958). In this study, the phytic acid reduction of GRF, GWF and GGLF were 65, 74 and $79 \%$ after 5 day germination, respectively (data not shown). The primary task of phytase in germinated grains is to provide inorganic phytate phosphate in the early stages of germination (Frolich et al 1988). The enzymatic hydrolysis of the phytate in seed has great prospects for phosphorus metabolism during the germination of cereals (Yamagata et al 1980). In another study performed by Ghavidel \& Prakash (2007), it was shown that the phytic acid content of raw and germinated lentil

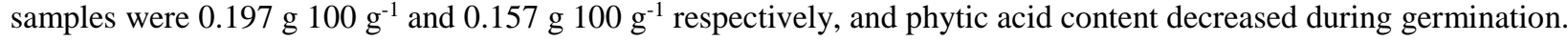

GGLF gave the highest calcium, potassium, phosphorus, zinc and iron content. The highest magnesium amount was observed with GRF during the germination period. Calcium, magnesium and iron content increased by increasing germination period. While potassium, phosphorus and zinc content of the GSF increased until the $3^{\text {rd }}$ day of germination, but after 3 days, a decrease of these parameters was observed. Surface color of cookies played a key-role for baking properties to determine the consumer preferences. $L^{*}, a^{*}, b^{*}$, SI (saturation index) and hue angle values of cookies made with GSF are given in Table 2. The average lightness value of the cookies made with GSF ranged from 63.81 to 67.48 (Table 2).As shown in Table 2, the use of GWF in cookie formulation resulted an increase in lightness and hue angle values compared to the other GSF. In cookie products, reducing lightness value could be expected due to caramelization and Maillard browning reactions that resulting in the darkening of product, generally (Manzocco et al 2000), but in this study, using GSF in the cookie formulation resulted in increase for lightness. Color variation of the cookies may be explained through surface smoothness. Purlis \& Salvadori (2009) reported that smooth surfaces were more effective to enhance the lightness than shrinkage. According to these antecedents using GSF resulted in smoother surface than control cookies and the lightness of cookies was clearer and brighter. While the cookies made with GWF resulted the highest lightness and hue angle values, the cookies made with GGLF gave the highest redness (a*), 
yellowness $\left(b^{*}\right)$ and saturation index values. The highest redness value of GGLF added cookies might be due to the low moisture content of cookie samples of GGLF. Pérez et al (2013) reported that the high water content in cookie results the cookie take more time to reach the water activity value corresponding to the maximum Maillard reaction rate.

Table 2-Effects of germinated seed flours and addition level on color properties of cookie samples ${ }^{1}$

\begin{tabular}{lccccc}
\hline $\begin{array}{l}\text { Germinated seeds flour / } \\
\text { Addition level (\%) }\end{array}$ & $L^{*}$ & $a^{*}$ & $b^{*}$ & $\begin{array}{c}\text { SI } \\
\text { (Saturation index) }\end{array}$ & Hue angle \\
\hline Germinated seeds flour & & & & & \\
GWF $^{2}$ & $67.48^{\mathrm{a}}$ & $4.29^{\mathrm{c}}$ & $26.31^{\mathrm{b}}$ & $26.66^{\mathrm{b}}$ & $80.75^{\mathrm{a}}$ \\
GRF & $63.81^{\mathrm{c}}$ & $6.11^{\mathrm{b}}$ & $25.64^{\mathrm{c}}$ & $26.38^{\mathrm{b}}$ & $76.59^{\mathrm{c}}$ \\
GGLF & $66.11^{\mathrm{b}}$ & $6.32^{\mathrm{a}}$ & $27.30^{\mathrm{a}}$ & $28.06^{\mathrm{a}}$ & $77.07^{\mathrm{b}}$ \\
\hline Addition level (\%) & & & & & \\
0 & $62.53^{\mathrm{c}}$ & $4.90^{\mathrm{c}}$ & $25.59^{\mathrm{c}}$ & $26.06^{\mathrm{c}}$ & $79.15^{\mathrm{b}}$ \\
5 & $69.35^{\mathrm{a}}$ & $5.02^{\mathrm{c}}$ & $27.35^{\mathrm{a}}$ & $27.81^{\mathrm{a}}$ & $79.59^{\mathrm{a}}$ \\
10 & $65.69^{\mathrm{b}}$ & $6.27^{\mathrm{a}}$ & $26.35^{\mathrm{b}}$ & $27.15^{\mathrm{b}}$ & $76.82^{\mathrm{c}}$ \\
15 & $65.63^{\mathrm{b}}$ & $6.11^{\mathrm{b}}$ & $26.37^{\mathrm{b}}$ & $27.12^{\mathrm{b}}$ & $76.99^{\mathrm{c}}$ \\
\hline
\end{tabular}

${ }^{1}$, Means with same letter within column are not significantly different $(\mathrm{P}<0.05)$; $\mathrm{GWF}^{2}$, Germinated Wheat Flour; GRF, Germinated Rye Flour; GGLF, Germinated Green Lentil Flour

Significant increases $(\mathrm{P}<0.01)$ were observed with GSF addition in lightness, redness, yellowness and saturation index values of cookie samples. The highest lightness, yellowness and saturation index values were obtained with a $5 \%$ addition level while the highest redness values were obtained with a $10 \%$ addition level.

The results were presented in Table 3 and shown that the diameters, thickness and spread ratio values of the cookie samples supplemented with GSF varied between 47.10 and $47.24 \mathrm{~mm}, 7.82$ and $7.97 \mathrm{~mm}, 5.93$ and 6.02 , respectively. It can be seen that there were a significant $(\mathrm{P}<0.01)$ increase in diameter of the samples with 10 and $15 \%$ addition level of GSF compared to control. The cookies made with GRF gave the highest thickness values while GRF addition resulted the lowest spread ratio values of cookies. The cookies containing GGLF and GWF gave the highest spread ratio values.

Table 3-Effects of germinated seed flours and addition level on textural properties of cookie samples ${ }^{1}$

\begin{tabular}{lccccc}
\hline $\begin{array}{l}\text { Germinated seeds flour } / \\
\text { Addition level }(\%)\end{array}$ & $\begin{array}{c}\text { Diameter } \\
(\mathrm{mm})\end{array}$ & $\begin{array}{c}\text { Thickness } \\
(\mathrm{mm})\end{array}$ & $\begin{array}{c}\text { Spread } \\
\text { Ratio }\end{array}$ & $\begin{array}{c}\text { Hardness } \\
(\mathrm{g})\end{array}$ & $\begin{array}{c}\text { Fracturability } \\
(\mathrm{g})\end{array}$ \\
\hline Germinated seeds flour & & & & & \\
GWF $^{2}$ & $47.24^{\mathrm{a}}$ & $7.86^{\mathrm{ab}}$ & $6.01^{\mathrm{a}}$ & $3428.55^{\mathrm{b}}$ & $39.87^{\mathrm{ab}}$ \\
GRF & $47.23^{\mathrm{a}}$ & $7.97^{\mathrm{a}}$ & $5.93^{\mathrm{b}}$ & $3704.88^{\mathrm{a}}$ & $40.13^{\mathrm{a}}$ \\
GGLF & $47.10^{\mathrm{a}}$ & $7.82^{\mathrm{b}}$ & $6.02^{\mathrm{a}}$ & $3209.49^{\mathrm{c}}$ & $39.43^{\mathrm{b}}$ \\
\hline Addition level (\%) & & & & & \\
0 & $47.05^{\mathrm{b}}$ & $7.89^{\mathrm{a}}$ & $5.96^{\mathrm{ab}}$ & $3452.81^{\mathrm{b}}$ & $39.72^{\mathrm{a}}$ \\
5 & $46.63^{\mathrm{b}}$ & $7.92^{\mathrm{a}}$ & $5.89^{\mathrm{b}}$ & $3774.91^{\mathrm{a}}$ & $39.84^{\mathrm{a}}$ \\
10 & $47.53^{\mathrm{a}}$ & $7.80^{\mathrm{b}}$ & $6.10^{\mathrm{a}}$ & $3428.29^{\mathrm{b}}$ & $39.61^{\mathrm{a}}$ \\
15 & $47.53^{\mathrm{a}}$ & $7.93^{\mathrm{a}}$ & $5.99^{\mathrm{ab}}$ & $3134.92^{\mathrm{c}}$ & $40.09^{\mathrm{a}}$ \\
\hline
\end{tabular}

${ }^{1}$, Means with same letter within column are not significantly different $(\mathrm{P}<0.05)$; $\mathrm{GWF}^{2}$, Germinated Wheat Flour; GRF, Germinated Rye Flour; GGLF, Germinated Green Lentil Flour

Data on the textural characteristics of cookies enriched with GSF are presented in Table 3. The tested cookies showed significant $(\mathrm{P}<0.01)$ differences according to GSF type and addition level of GSF with respect to hardness. The hardness of the cookies was found between 3209.49 and $3704.88 \mathrm{~g}$ and the fracturability values were observed between 39.43 and $40.13 \mathrm{~g}$. The lowest hardness and fracturability value of the cookies was observed for cookies containing GGLF, while the GRF addition resulted in the highest hardness and fracturability values. Wani et al (2012) reported that, high hardness values are related to protein content, high protein content resulted in a more hard structure and this result was due to the interaction between protein and starch. Another is the fiber content that affects the texture. 
GRF addition decreased the spread ratio and increased the hardness of cookies that may be due to dilution of gluten or less protein content of rye compare to the other seeds and less water availability for hydration. As the addition level of GSF increased in cookies, fracturability values were not affected while hardness of cookies increased at $5 \%$ addition level and decreased at higher levels. It is thought that the fluctuations in the hardness values are caused by the differences in the moisture content of the cookie samples.

Baranzelli et al (2018) noted that the increase in the germination time reduced tenacity and increased extensibility of the flours. Also we know that tenacious gluten composites were used to make bread, whereas extensible gluten composites were used for cake and cookie production (Melini et al 2017; Sanchez-Garcia et al 2015). So that addition of GSF is more suitable for cookie making than bread making.

The moisture and ash values of cookies made with GSF were given in Figure 1. The moisture value of the cookie samples were between $2.30 \%$ and $5.42 \%$, the average was $3.90 \pm 1.23 \%$. The cookies made with GRF gave the highest moisture content. The usage of GGLF gave the lowest moisture content. Cornejo \& Rosel (2013) mentioned that germinated rice flour gave lower moisture content than raw rice flour. The ash amounts of the cookie samples varied between 1.55 and $1.73 \%$. The values of ash did not significantly $(\mathrm{P}>0.05)$ varied among the three GSF. The results showed that an increase was observed in the ash values according to addition level of GSF. This result was associated to the increase in the relative proportion of minerals due to the loss of other seed storage reserves reported by Borek et al (2006).
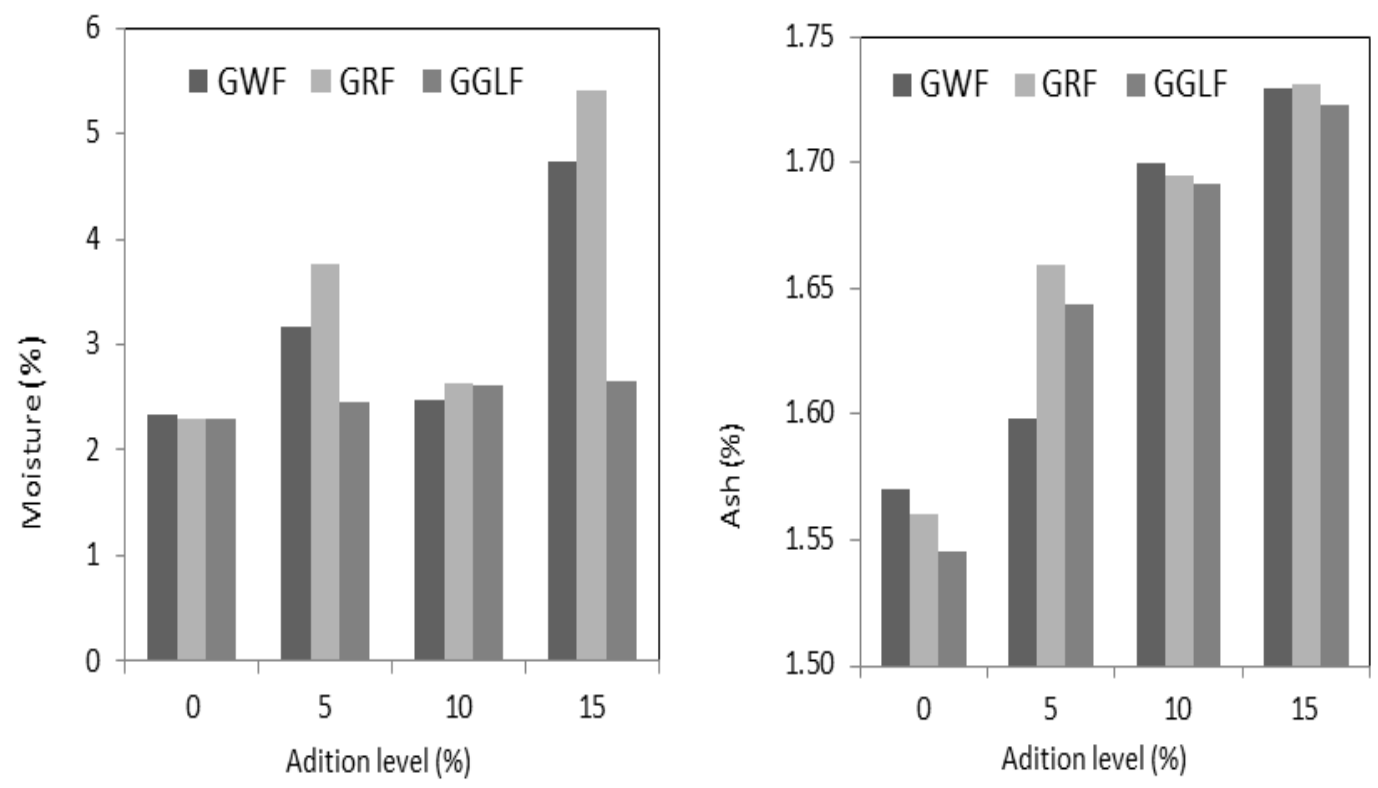

Figure 1- Moisture and ash contents of cookie samples (GWF, Germinated Wheat Flour; GRF, Germinated Rye Flour; GGLF, Germinated Green Lentil Flour)

Nutritional analyzes were performed at the end of the $5^{\text {th }}$ day germination period and with only $15 \%$ substitution rate of the GSF added cookie samples. The effects of GSF addition on the phytic acid content of cookies are summarized in Table 4. The amount of phytic acid in the control cookie and GWF, GRF, GGLF added cookie samples were $222.60 \pm 5.94,195.30 \pm 2.97,203.70 \pm 2.97,191.10 \pm 2.97 \mathrm{mg} 100 \mathrm{~g} \mathrm{~g}^{-1}$, respectively. The lowest amount of phytic acid was determined with GGLF and GWF added cookie samples, while the highest amount of phytic acid was obtained from control cookie sample (made with ungerminated wheat flour). Germination process decreases the phytic acid content due to the increasing phytase enzyme during germination. A comparable observation was described by Azeke et al (2011) who found that during germination, the level of phytase activity increased and reached its maximal value after six (5-fold), five (7-fold), and eight (6-fold) days of germination for maize, millet, and wheat and also on the seven (16and 3-fold respectively) for rice and sorghum. Usually, legume based food product contain higher phytate contents than cereal-based food products. But in present study, GGLF added cookie samples gave lower phytic acid content than cereal based control cookie sample. Germination process is effective for decreasing the phytic acid content of legume based products. 
Table 4-Effects of germinated seed flours on mineral contents of cookie samples ${ }^{1}$

\begin{tabular}{|c|c|c|c|c|c|c|c|c|}
\hline $\begin{array}{l}\text { Germinated } \\
\text { Seed Flours }\end{array}$ & $\begin{array}{l}\text { Phytic } \\
\text { Acid } \\
\left(m g 100 g^{-1}\right)\end{array}$ & $\begin{array}{c}T P C^{3} \\
\left(m g G A E k g^{I}\right)\end{array}$ & $\begin{array}{c}\text { Calcium } \\
(\mathrm{Ca}) \\
\left(\mathrm{mg} 100 \mathrm{~g}^{-1}\right)\end{array}$ & $\begin{array}{c}\text { Iron } \\
(\mathrm{Fe}) \\
\left(m g 100 g^{-1}\right)\end{array}$ & $\begin{array}{c}\text { Potassium } \\
(\mathrm{K}) \\
\left(\mathrm{mg} 100 \mathrm{~g}^{-1}\right)\end{array}$ & $\begin{array}{c}\text { Magnesium } \\
(\mathrm{Mg}) \\
\left(\mathrm{mg} 100 \mathrm{~g}^{-1}\right)\end{array}$ & $\begin{array}{c}\text { Phosphorus } \\
(P) \\
\left(m g 100 g^{-1}\right)\end{array}$ & $\begin{array}{c}\text { Zinc } \\
(\mathrm{Zn}) \\
\left(m g 100 g^{-1}\right)\end{array}$ \\
\hline Control & $222 \pm 5.94^{\mathrm{a}}$ & $713.5 \pm 6.36^{\mathrm{d}}$ & $32.04 \pm 0.02^{\mathrm{d}}$ & $1.54 \pm 0.03^{b}$ & $122.23 \pm 0.08^{\mathrm{d}}$ & $19.66 \pm 0.02^{\mathrm{d}}$ & $557.16 \pm 0.72^{\mathrm{a}}$ & $0.84 \pm 0.01^{\mathrm{c}}$ \\
\hline $\mathrm{GWF}^{2}$ & $195 \pm 2,97^{\mathrm{c}}$ & $838 \pm 4.24^{\mathrm{c}}$ & $41.42 \pm 0.01^{b}$ & $1.47 \pm 0.01^{\mathrm{c}}$ & $146.27 \pm 0.17^{c}$ & $31.62 \pm 0.03^{b}$ & $507.17 \pm 0.63^{c}$ & $1.01 \pm 0.01^{\mathrm{a}}$ \\
\hline GRF & $203 \pm 2.97^{b}$ & $904.5 \pm 4.95^{b}$ & $54.50 \pm 0.01^{\mathrm{a}}$ & $1.04 \pm 0.01^{\mathrm{d}}$ & $162.49 \pm 0.36^{\mathrm{b}}$ & $39.05 \pm 0.01^{\mathrm{a}}$ & $303.64 \pm 0.66^{\mathrm{d}}$ & $0.95 \pm 0.01^{b}$ \\
\hline GGLF & $191 \pm 2.97^{c}$ & $1095 \pm 4.24^{\mathrm{a}}$ & $36.71 \pm 0.01^{\mathrm{c}}$ & $1.83 \pm 0.02^{\mathrm{a}}$ & $195.07 \pm 0.28^{\mathrm{a}}$ & $26.97 \pm 0.01^{\mathrm{c}}$ & $559.90 \pm 0.90^{\mathrm{b}}$ & $1.00 \pm 0.02^{\mathrm{a}}$ \\
\hline
\end{tabular}

1, means with same letter within column are not significantly different $(\mathrm{P}<0.05)$; ${ }^{2}$, GWF: Germinated Wheat Flour; GRF, Germinated Rye Flour; GGLF, Germinated Green Lentil Flour; ${ }^{3}$, TPC, Total Phenolic content

The total phenolic content (TPC) of cookie samples was presented in Table 4. Important phenolic compounds found in cereals; phenolic acids, flavonoids and tannins, which are concentrated in the bran fraction of cereal grains, are found in free, conjugated, and bound forms. Total phenolic content of control and GWF, GRF, GGLF added cookie samples were $713.50 \pm 6.36,838.00 \pm 4.24,904.50 \pm 4.95$ and $1095.00 \pm 4.24 \mathrm{GAE} \mathrm{mg} \mathrm{kg}^{-1}$, respectively. TPC increased by $17.5,27$, $55 \%$ with GWF, GRF and GGLF addition in cookie formulation compared to control, respectively. As reported by Gawlik-Dziki et al (2016) after 4 days germination process, total phenolic content of wheat samples increased from 2.25 GAE mg g ${ }^{-1}$ to 4.35 GAE $\mathrm{mg} \mathrm{g}^{-1}$. GGLF with rich TPC had a more dominant effect on TPC of cookie samples compared to the other GSF. Lentil has higher total phenolic and tannin content compared to other legumes. The TPC of lentils is thought to contribute significantly to the total antioxidant activity. The cotyledon of the lentil mainly contains non-flavonoid phenolic compounds, while the shell layer contains flavonoids.

Table 4 shows some mineral contents ( $\mathrm{Ca}, \mathrm{Fe}, \mathrm{K}, \mathrm{Mg}, \mathrm{P}$ and $\mathrm{Zn}$ ) in each of the cookies enriched with $15 \%$ level of

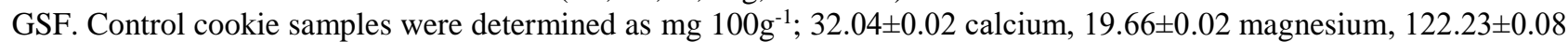
potassium, $557.16 \pm 0.72$ phosphorus, $0.84 \pm 0.01$ zinc and $1.54 \pm 0.03$ irons. The addition of GSF in cookie formulation increased the $\mathrm{Ca}, \mathrm{K}, \mathrm{Mg}$ and $\mathrm{Zn}$ content cookies compared to the control cookie sample. According to test results of cookie samples; the highest calcium and magnesium values were observed with cookies made GRF; the highest iron, potassium and zinc values were determined with GGLF cookies, while the lowest calcium, potassium, magnesium and zinc values were obtained from control cookie samples. The average daily mineral quantities are as follows: Calcium $1000 \mathrm{mg}$, iron $18 \mathrm{mg}$, potassium $3500 \mathrm{mg}$, magnesium $400 \mathrm{mg}$, phosphorus $1000 \mathrm{mg}$, zinc $15 \mathrm{mg}$. 100 grams of cookies made with GRF supplied $5.45 \%$ of the daily calcium content, $9.76 \%$ of the magnesium content, $4.64 \%$ of the amount of potassium, $30.36 \%$ of the phosphorus content, $6.33 \%$ of the zinc content, $5.78 \%$ of the amount of iron. 100 grams of cookies made with GGLF supplied $3.67 \%$ of the daily calcium content, $6.74 \%$ of the magnesium content, $5.57 \%$ of the amount of potassium, $55.99 \%$ of the amount of phosphorus, $6.67 \%$ of the zinc amount, $10.17 \%$ of the amount of iron.

Sensory analyzes were performed in cookies enriched with $0,5,10$ and 15\% GSF and shown in Table 5. The average organoleptic values of cookie samples evaluated between 1-5 points; the color values were 4.22-4.62, the appearance values were 4.23-4.45, the friability was 4.40-4.54, the taste was 4.10-4.57, the odor was 4.35-4.78 and the overall appreciation values were found between 4.32 and 4.51. The general appreciation of the cookies produced with the addition of GSF was evaluated as not different from each other. Generally, the highest appreciation value was found in 5\% GWF added cookies and control cookies. In particular, the GWF added cookie received the highest $(\mathrm{P}<0.05)$ score for friability and taste, and the lowest score for odor. The cookies made with the GGLF gave the highest color and odor values, while the lowest scores were received for appearance with GGLF. The highest friability score was determined in cookie samples with supplemented GWF, while the most appreciated taste scores were determined in these samples. The increasing addition level did not affect the appearance of cookies. Color is one of the most important visual characteristic of cookies that strongly influences consumer's choice. Color scores was found similar scores up to $10 \%$ substitution rate, whereas more than $10 \%$ addition level decreased color score. Taste values showed similar scores with the control cookie samples up to 5\% addition level, adding more than 5\% level, resulting in a decrease in taste scores. Odor scores decreased with increasing addition level. In general, the addition of GSF to $5 \%$ level resulted in general appreciation scores similar to the control cookie samples, which led to a decrease in the probability of more addition levels. 
Table 5-Effects of germinated seed flours and addition level on sensorial cookie properties ${ }^{1}$

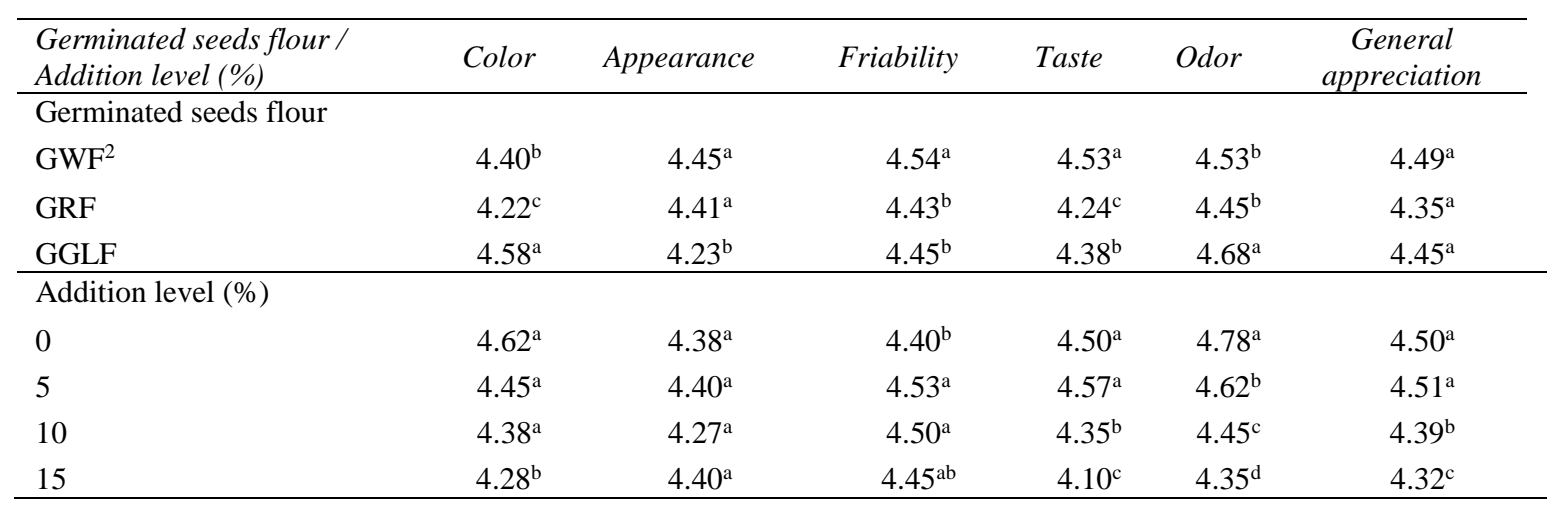

${ }^{1}$, Means with same letter within column are not significantly different $(\mathrm{P}<0.05)$; GWF ${ }^{2}$, Germinated Wheat Flour; GRF, Germinated Rye Flour; GGLF, Germinated Green Lentil Flour

\section{Conclusions}

The GSF is an alternative source in cookie formulation for nutritional enrichment. In this study, chemical, nutritional and sensorial properties of cookies enriched with GSF were investigated. Germination improved the nutritional quality such as ash, protein, total phenolic content, minerals and decreased the anti-nutritional factor as phytic acid. According to sensorial evaluation, the addition of GSF to 5\% level resulted in general appreciation scores similar to the control cookie samples. Result of this study revealed that more nutritious cookies can be produced by up to 5\% addition level of GSF and this formulation of cookie can be beneficially affects the nutritive composition and also does not impair sensorial attributes of cookies.

\section{Acknowledgements}

This study is a part of M.Sc. thesis of the first author. The authors would like to thank Unit of Scientific Research Projects of Necmettin Erbakan University (Project number, BAP-161319017) for financially supporting this research project.

\section{References}

AACC (2000). Approved methods of the AACC (10 ${ }^{\text {th }}$ ed.). St. paul, MN, USA: American Association of Cereal Chemists

Ashton M \& Williams C P (1958). The phosphorus compounds of oats. I. The content of phytate phosphorus. Journal of the Science of Food and Agriculture 9: 505-511

Azeke M A, Egielewa S J, Eigbogbo M U \& Ihimir I G (2011). Effect of germination on the phytase activity, phytate and total phosphorus contents of rice (Oryza sativa), maize (Zea mays), millet (Panicum miliaceum), sorghum (Sorghum bicolor) and wheat (Triticum aestivum). Journal of Food Science and Technology 48(6): 724-729

Baranzelli J, Kringel D, Colussi R, Fernandes P F, Camargo A B, Miranda M, Zavareze E \& Dias Á (2018). Changes in enzymatic activity, technological quality and gamma-aminobutyric acid (GABA) content of wheat flour as affected by germination. $L W T$ Food Science and Technology 90: 483-490

Beta T, Nam S, Dexter J E \& Sapirstein H D (2005). Phenolic content and antioxidant activity of pearled wheat and roller-milled fractions. Cereal Chemistry 82(4): 390-393

Borek S, Ratajczak W \& Ratajczak L (2006). Ultrastructural andenzymatic research on the role of sucrose in mobilization ofstorage lipids in germinating yellow lupine seeds. Plant Science 170: 441-452

Cornejo F \& Rosel C M (2013). Influence of germination time of brown rice in relation to flour and gluten free bread quality. Journal of Food Science and Technology 52(10): 6591-6598 
Cunha-Queda A C \& Beirao da Costa M L (1994). A RSM study to the effect of controlled germination in Lupinus luteus alkaloid content. In J. M. Neves-Martins \& M. L. Beirao da Costa (Eds.), Advances in lupin research Lisboa: Instituto Superior de Agronomia (ISA press) pp. 521-523

Ertaş N (2015). Technological and Chemical Characteristics of Breads Made With Lupin Sprouts. Quality Assurance and Safety of Crops \& Foods 7(3): 313-319

Frolich W, Wahlgren M \& Drakenberg T (1988). Studies on phytase activity in oats and wheat using p-nmr spectroscopy. Journal of Cereal Science 8: 47-53

Gao L, Wang S, Oomah B D \& Mazza G (2002). Wheat Quality: Antioxidant Activity of Wheat Millstreams, in: Wheat Quality Elucidation. In. P. Ng \& C. W. Wrigley (Eds.). AACC International: St. Paul. MN 219-233

Gawlik-Dziki U, Dziki D, Nowak R, Swieca M \& Olech M (2016). Influence of sprouting and elicitation on phenolic acids profile and antioxidant activity of wheat seedlings. Journal of Cereal Science 70: 221-228

Ghavidel R A \& Prakash J (2007). The impact of germination and dehulling on nutrients, antinutrients, in vitro iron and calcium bioavailability and in vitro starch and protein digestibility of some legume seeds. Learning with Technologies 40: 1292-1299

Haugh W \& Lantzsch H J (1983). Sensitive method for the rapid determination of phytate in cereals and cereal product. Journal of the Science of Food and Agriculture 34: 1423-1426

Katina K, Liukkonen K H, Kaukovirta-Norja A, Adlercreutz H, Heinonen S M, Lampi A M, Pihlava J M \& Poutanen K (2007). Fermentation-induced changes in the nutrition value of native or germinated rye. Journal of Cereal Science 46: 348-355

Kim H Y, Hwang I G, Kim T M, Wood S K, Park D S, Kim J H, Kim D J, Lee J, Lee Y R \& Jeong H S (2012). Chemical and functional components in different parts of rough rice (Oryza sativa L.) before and after germination. Food Chemistry 134: 288293

Lintschinger J, Fuchs N, Moser H, Jager R, Hlebeina T, Markolin G \& Gossler W (1997). Uptake of variou trace elements during germination of wheat, buckwheat and quinoa. Plant Foods for Human Nutrition 50: 223-237

Lorenz K (1980). Cereal sprout: composition, nutritive value, food applications. CRC-Critical Reviews Food Science Nutition 13(4): 353-385

López-Amorós M L, Hernández T \& Estrella I (2006). Effect of germination on legume phenolic compounds and their antioxidant activity. Journal of Food Composition and Analysis 19: 277-283

Manzocco L, Calligaris S, Mastrocola D, Nicoli M C \& Lerici C R (2000). Review of nonenzymatic browning and antioxidant capacity in processed foods. Trends in Food Science and Technology 11: 340-346

Melini F, Melini V, Luziatelli F \& Ruzzi M (2017). Current and forward-looking approaches to technological and nutritional improvements of gluten-free bread with legume flours: A critical review. Comprehensive Reviews in Food Science and Food Safety 16: 1101-1122

Moongngarm A \& Saetung N (2010). Comparison of chemical compositions and bioactive compounds of germinated rough rice and brown rice. Food Chemistry 122: 782-788

Öztürk İ (2008). Çimlendirilmiş buğday tanesinin kimyasal özelliklerinin belirlenmesi ve doğal gıda katkı maddesi olarak değerlendirilme imkanlarının araştırılması, Yüksek Lisans Tezi, Erciyes Üniversitesi Fen Bilimleri Enstitüsü Gıda Mühendisliği Anabilim Dalı, Kayseri, 121

Pérez S, Matta E, Osella C, Torre M \& Sánchez H D (2013). Effect of soy flour and whey protein concentrate on cookie color. LWT - Food Science and Technology 50(1): 120-125

Purlis E \& Salvadori V (2009). Modeling the browning of bread during baking. Food Research International 42: 865-870

Reddy N R, Sathe S K \& Salunkhe D K (1982). Phytates in legumes and cereais. Advances in Food Research 28: 1 
Rosa-Millán J, Heredia-Olea E, Perez-Carrillo E, Guajardo-Flores D \& Serna-Saldíva S R O (2019). Effect of decortication, germination and extrusion on physicochemical andin vitroprotein and starch digestion characteristics of black beans (Phaseolus vulgaris L.). LWT - Food Science and Technology 102: 330-337

Sanchez-Garcia M, Álvaro F, Peremarti A, Martín-Sánchez J A \& Royo C (2015). Changes in bread-making quality attributes of bread wheat varieties cultivated in Spain during the $20^{\text {th }}$ century. European Journal of Agronomy 63: 79-88

Shin D J, Kim W \& Kim Y (2013). Physicochemical and sensory properties of soy bread made with germinated, steamed, and roasted soy flour. Food Chemistry 141: 517-523

Siro I, Kapolna E, Kapolna B \& Lugasi A (2008). Functional food: product development, marketing and consumer acceptance- a review. Appetite 51: 456-467

Skujins S (1998). Handbook for ICP-AES (Vartian-Vista). A Short Guide to Vista Series ICP-AES Operation. Variant Int. AG. Zug. version 1.0. Switzerland

Sung H G, Shin H T, Ha J K, Lai H L, Cheng K J \& Lee J H (2005). Effect of germination temperature on characteristics of phytase production from barley. Bioresource Technology 96: 1297-1303

Tarzi B G, Gharachorloo M, Baharinia M \& Mortazavi S A (2012). The effect of germination on phenolic content and antioxidant activity of chickpea. Iranian journal of pharmaceutical research. International Journal of Production Research 11(4): 1137

Urbano G, Lopez-Jurado M, Hernandez J, Fernandez M, Moren M C, Fr1'as J, Diaz-Pollan C, Prodanov M \& Vidal-Valverde C (1995). Nutritional assessment of raw, heated and germination lentils. Journal of Agricultural and Food Chemistry 43: 18711877

Wani A A, Sogi D S, Singh P, Sharma P \& Pangal A (2012). Dough-handling and cookie-making properties of wheat flourwatermelon protein isolate blends. Food and Bioprocess Technology 5: 1612-1621

Wilhelmson A, Oksman-Caldentey K M, Laitila A, Suortti T, Kaukovirta-Norja A \& Poutanen K (2001). Development of a germination process for producing high $\beta$-glucan, whole grain food ingredients from oat. Cereal Chemistry 78: 715-720

Yamagata H, Tanaka K \& Kasai K (1980). Prufication and characterization of acid phoshotase in aleurone particles of rice grains. Plant Cell Physiology 21(8): 1149-1460

Yang F (2000). Nutritional evaluation of germinated wheat and its use in a nutritional bar, Thesis of Master of Science, Edmonton, Canada, 106

Yeo J \& Shahidi F (2017). Effect of hydrothermal processing on changes of insoluble-bound phenolics. Journal of Functional Foods 38: $716-722$

Zilic S, Basic Z, Sukalovic V H T, Maksimovic V, Jankovic M \& Filipovic M (2014). Can the sprouting process applied to wheat improve the contents of vitamins and phenolic compounds and antioxidant capacity of the flour. International Journal of Food Science and Technology 49: 1040-1047 